\title{
Long-term results of the patients who were applied laparoscopic adjustable gastric banding
}

\author{
Sabri Özden ${ }^{1}$, Barış Saylam ${ }^{1}$, Fatih Mehmet Avşar ${ }^{1}$ \\ ${ }^{1}$ Clinic of Surgery, Ankara Numune Training and Research Hospital, Ankara, Turkey
}

\begin{abstract}
Objective: The most effective treatment step in morbid obesity is surgical treatment. The purpose of the present study was to investigate the long-term follow-up results and success rates in laparoscopic adjustable gastric banding.

Material and Methods: The change in body mass index, percentage of excess weight loss, comorbidities, and resulting complications were investigated in 220 patients who were morbidly obese and applied laparoscopic adjustable gastric band between April 2006 and February 2012 , throughout the 6-year follow-up period. Forty-six patients who did not show up for their routine follow-ups were excluded from the study.

Results: In the present study, band removal percentage was 35.63\%. The percentage of excess weight loss in patients who were followed up without removal of the band was $46.03 \%$. Complications were observed in $46.5 \%$ of the patients. The most frequently observed complication among the major complications was band intolerance, which is also the most common cause of band removal. Band removal was considered as a failure in laparoscopic adjustable gastric band operations, and patients were referred to other surgical methods.

Conclusion: When improved patient compliance and careful and close patient follow-up are provided in the early stages of laparoscopic adjustable gastric band application, it may be possible to reach percentage of excess weight loss results that would be the nearest to those achieved by gastric bypass or sleeve gastrectomy methods. However, high complication rates and necessity to perform other bariatric surgical procedures in the majority of the patients in the long-term follow-up suggest that the laparoscopic adjustable gastric band operation is not the first choice in bariatric surgery.
\end{abstract}

Keywords: Body mass index, laparoscopic adjustable gastric band, laparoscopic sleeve gastrectomy, laparoscopic Roux-en-Y gastric bypass, percentage of excess weight loss

Cite this article as: Özden S, Saylam B, Avşar FM. Longterm results of laparoscopic adjustable gastric banding. Turk J Surg 2019; 35 (2): 79-85

\section{Corresponding Author}

\section{Sabri Özden}

E-mail: drsabriozden@gmail.com

Received: 26.11 .2017

Accepted: 19.02 .2018

Available Online Date: 18.09.2018

O Copyright 2019 by Turkish Surgical Society Available online at www.turkjsurg.com

DOI: $10.5578 /$ turkjsurg. 4038

\section{INTRODUCTION}

Morbid obesity is a life-threatening health problem that reduces an individual's quality of life by preventing his/her sociocultural life with many comorbid diseases and complications (1). In the surgical treatment of obesity, laparoscopic adjustable gastric band (LAGB) surgery is a restrictive surgical procedure. It appears to be an advantageous surgical technique as it does not involve any anastomosis or resection, it is reversible, there are very few life-threatening complications, and it is a minimally invasive intervention.

The main purpose of the present study was to investigate success rates, complications, their incidence, and treatment and to determine improvement rates of existing comorbidities in patients who underwent LAGB operation.

\section{MATERIAL and METHODS}

The study was conducted between April 2006 and February 2012 in our clinic on 220 patients who were applied LAGB operation. Forty-six patients who did not show up for their routine follow-ups and could not be reached were excluded from the study. Data were analyzed retrospectively using hospital records, outpatient applications, routine follow-ups, and surveys. The local ethics committee approved the study (approval no. 2013-545). Informed consent was not required owing to the retrospective nature of the study.

Patients who were applied LAGB were selected according to the National Institute of Health (NIH-1991) guide (2). Surgical procedures of all patients were performed by the same surgical team. As to the surgical technique, the perigastric technique was applied to the first 82 patients, and the pars flaccida technique was applied to the other 92 patients $(3,4)$. The bands of 82 patients were inflated 2 ccs with per- 
igastric technique during the operation and readjusted during the follow-up, 4 weeks later. On the other hand, the bands of 92 patients who were operated with pars flaccida technique were inflated for the first time 4 weeks later after the operation.

Majority of the patients were discharged in 1-2 days in the postoperative period. Patients were checked in week 1 by esophagus stomach duodenum (ESD) fluoroscopy. A semi-solid diet was recommended at postoperative week 4 to the patients. If no problem existed in the ESD fluoroscopy performed in week 4 , the band was inflated with lopamiro-SF under fluoroscopy. Patients were called for control appointment every 2 weeks during the first 6 months. After the first 6 months, patients were called once in 6 weeks if the band was adjusted in a way so as to achieve $1-2 \mathrm{~kg} /$ week weight loss. In the second year, they were evaluated every 3 months, monitoring body mass index (BMI), ESD fluoroscopy, and blood tests. After the second year, patients have been followed up two times in 1 year. In addition to routine follow-ups, patients were followed up by a dietician.

\section{Complications}

Complications that could be treated medically or with simple surgical procedures in a relatively simpler way and have less negative effects on weight loss were classified as minor complications (port infection, port tube separation, and port slippage). Those that could be treated in a more difficult way, such as removing the band with general anesthesia, and that had more negative effects on weight loss were considered as major complications (band opening, band slippage, pouch enlargement, band erosion/migration, and band intolerance).

Slippage: The cephalic prolapse of the antrum with consequent caudal dislocation of the band is called band slippage. Dysphagia and vomiting are major symptoms of band slippage (5).

Pouch enlargement: Dilatation of the pouch, regardless of changes in the angle of the band, is called pouch enlargement. If a patient has symptoms, such as lack of satiety, regurgitation, heartburn, or chest pain, a clinician has to consider pouch enlargement (5).

Band erosion/migration: Band erosion/migration means that the band in place after adjustable gastric band surgery has grown into the stomach. In patients, one or more symptoms may be present, such as vague abdominal pain, decreased sensation regarding the procedure, decreased sensation in satiety, weight gain, or inability to lose weight. The diagnosis of this complication was made as the band was seen partially or fully in the stomach by endoscopy (6).

Band intolerance: Band intolerance is a condition where full food intolerance develops in patients. Patients complain of severe vomiting.

In these patients, in ESD fluoroscopy or even if pathology was not detected in endoscopy, proton pump inhibitors and medi- cal treatments with antiemetics, through draining all the liquid in the band, were attempted. If persistent vomiting continued despite medical treatment more than 1 month or esophagitis was detected in endoscopy and it did not improve or symptoms reoccurred after refilling, band removal was applied.

\section{Weight Loss}

In the present study, the applied method was considered to be unsuccessful in patients whose percentage of excess weight loss (\%EWL) was $<25 \%$.

The \%EWL was calculated as follows:

$\% \mathrm{EWL}=[$ (operative weight-follow-up weight)/operative weightideal weight] $\times 100$.

The ideal body weight of each patient was estimated based on a target BMl of $25 \mathrm{~kg} / \mathrm{m}^{2}$ (7).

\section{Statistical Analysis}

Data were screened retrospectively. For numerical data, they were analyzed by average, standard deviation, and minimum and maximum values. For qualitative data, they were analyzed according to the distribution of number and percentage variables. For non-parametric values, the comparison of numerical data with multiple groups was performed by the Kruskal-Wallis test, and the comparison with dual groups was analyzed by the Mann-Whitney $U$ test. Percentage values were analyzed by the Chi-square test. $p<0.05$ was considered as statistically significant.

\section{RESULTS}

Between April 2006 and February 2012, 174 out of 220 patients who were applied LAGB operation in our clinic were included in the study. The percentage of followed-up patients is 79.09\%.

In the study, there were 141 women and 33 men. Average age was 35.24 (18-62) years. Postoperative average BMI was 50.07 (36-74) $\mathrm{kg} / \mathrm{m}^{2}$. There was no operative mortality. Postoperative average follow-up period was 45.37 months.

\section{Complications}

In the study, 66 (37.9\%) major complications were observed (Table 1).

Slippage: Slippage was observed in 19 (10.91\%) patients. In these patients, the average time that passed from the first operation was 24 (10-48) months. Band removal was performed in 15 out of the 19 patients. Among these patients, 4 were applied laparoscopic sleeve gastrectomy (LSG), and 7 were applied laparoscopic Roux-en-Y gastric bypass.

Pouch enlargement: Pouch enlargement was observed in 6 (3.44\%) patients. For pouch enlargement, the average time that passed from the first operation was 29 (12-48) months. Only one out of 6 patients was applied rebanding. The other patients' bands were removed. Sufficient weight loss was achieved in the patient who was applied rebanding. 
Table 1. Distribution of the complications

\begin{tabular}{|l|c|}
\hline Complications & n (\%) \\
\hline Minor complications & $30(17.22)$ \\
\hline Port infection & $19(10.91)$ \\
\hline Port tube separation & $4(2.29)$ \\
\hline Port slippage & $7(4.02)$ \\
\hline Major complications & $66(37.9)$ \\
\hline Band opening & $5(2.87)$ \\
\hline Slippage & $19(10.91)$ \\
\hline Pouch enlargement & $6(3.44)$ \\
\hline Band erosion/migration & $14(8.04)$ \\
\hline Band intolerance & $22(12.64)$ \\
\hline
\end{tabular}

Band erosion/migration: Band erosion was observed in 14 (8.04\%) patients. For band erosion, the average time that passed from the first operation was 28 (12-60) months.

Bands of all patients with band erosion were removed. Among these patients, 2 patients were applied LSG, 1 patient was applied laparoscopic gastric bypass, and 1 patient was applied open gastric bypass.

Band intolerance: Band intolerance was the most frequently observed complication in the present study, and it was the most common cause of band removal. It was observed in 22 (12.64\%) patients. The average time that passed for band intolerance was 30 (6-72) months.

In these patients, band removal was performed in 15 patients, and 7 patients responded to medical treatment. Among these patients whose band was removed, 4 patients were applied LSG, 5 patients were applied laparoscopic gastric bypass, and 1 patient was applied open gastric bypass.

Band removal: Band removal was applied to 62 (35.63\%) patients. Of these patients, 33 (18.96\%) underwent a different sur-

Table 2. Causes for band removal and average time for band removal

\begin{tabular}{|l|c|c|}
\hline Causes for band removal & $\mathbf{n}(\%)$ & $\begin{array}{c}\text { Average month } \\
\text { (min-max) }\end{array}$ \\
\hline Band opening & $3(1.72)$ & $33(3-60)$ \\
\hline Slippage & $13(7.41)$ & $24(10-48)$ \\
\hline Pouch enlargement & $7(4.02)$ & $29(12-48)$ \\
\hline Band erosion/migration & $14(8.04)$ & $28(12-60)$ \\
\hline Band intolerance & $15(8.62)$ & $30(6-72)$ \\
\hline $\begin{array}{l}\text { Inability to lose weight/ } \\
\text { Patient's desire }\end{array}$ & $10(5.74)$ & $31(4-60)$ \\
\hline Total & $62(35.63)$ & $28(2-72)$ \\
\hline & & \\
\hline
\end{tabular}

gical procedure (Table 2). The average time from the first operation date was 28 (2-72) months.

\section{Weight Loss}

When annual weight checks and BMI of 174 patients were analyzed, four separate groups were formed: patients who were followed up without band removal, patients who did not want another operation after band removal, patients who were applied LSG after band removal, and patients who were applied gastric bypass after band removal.

When 112 patients who were followed up without band removal were considered, the average weight dropped from $138.36 \mathrm{~kg}$ to $101.29 \mathrm{~kg}$. On the other hand, the average BMI dropped from $48.54 \mathrm{~kg} / \mathrm{m}^{2}$ to $36.24 \mathrm{~kg} / \mathrm{m}^{2}$. Compared with the other groups with an average weight loss of $38.19 \mathrm{~kg}$ and an average BMI of $12.29 \mathrm{~kg} / \mathrm{m}^{2}$, the results were close to the gastric bypass group and better than the other groups (Table 3).

When mean \%EWL was considered, it was seen that the best group was the bypass group with $48.98 \%$, followed by the patient group who was followed up by the band. It was noteworthy that \%EWL was $<25 \%$ for the patient group who did not undergo another surgery after band removal.

When the patient group who was followed up by the band was compared with the patient group who was not performed another surgery after band removal, there was a statistically significant difference between the groups in terms of the end of follow-up weight, BMI, and \%EWL $(p<0.05)$. When this group was compared with the group who was performed LSG after band removal, there was a statistically significant difference between the groups in terms of the end of follow-up weight, BMI, and $\% E W L(p<0.05)$. However, when this group was compared with the group who underwent gastric bypass, the difference between the groups in terms of the end of follow-up weight, BMI, and \%EWL was not statistically significant ( $p>0.05$ ) (Table 3).

\section{Comorbidities}

Various comorbid diseases were present in 43 (24.7\%) patients. These diseases were type 2 diabetes mellitus in 13 (7.4\%) patients, essential hypertension in $16(9.1 \%)$ patients, arthralgia in 8 (4.5\%) patients, and sleep apnea in 6 (3.4\%) patients.

In 10 out of 13 patients with diabetes, some improvements, such as removing oral antidiabetic drugs or reducing insulin dosage, were observed. Some improvements were also observed in 11 out of 16 patients with hypertension in the form of a reduction in drug dosage or complete cessation and in 5 out of 8 patients with arthralgia in the form of a reduction in non-steroid anti-inflammatory drug use or complete cessation. On the other hand, in 4 out of 6 patients who had sleep apnea and had to use a continuous positive airway pressure device, the need for the device was reduced, or it was no longer needed (Table 4). 
Table 3. Average weight, BMI, EWL changes in patient groups who were applied different surgical procedures (*Kruskal-Wallis test)

\begin{tabular}{|c|c|c|c|c|c|c|}
\hline & All patients & $\begin{array}{l}\text { Band not } \\
\text { removed }\end{array}$ & $\begin{array}{c}\text { Band removed, No } \\
\text { other surgery }\end{array}$ & $\begin{array}{c}\text { Band removed } \\
+ \text { LSG }\end{array}$ & $\begin{array}{c}\text { Band removed + } \\
\text { Gastric bypass }\end{array}$ & $\mathbf{p}^{*}$ \\
\hline Number of patients & 174 & 112 & 28 & 13 & 21 & \\
\hline $\begin{array}{l}\text { Preoperative average } \\
\text { weight }(\mathrm{kg})\end{array}$ & 138.3 & 138.36 & 136.53 & 141.53 & 137.55 & 0.816 \\
\hline $\begin{array}{l}\text { Preoperative average } \\
\mathrm{BMI}\left(\mathrm{kg} / \mathrm{m}^{2}\right)\end{array}$ & 49.12 & 48.54 & 50.07 & 49.8 & 50.81 & 0.927 \\
\hline $\begin{array}{l}\text { End of follow-up } \\
\text { average weight (kg) }\end{array}$ & 103.61 & 101.29 & 113.82 & 112.3 & 97.4 & 0.013 \\
\hline $\begin{array}{l}\text { End of follow-up } \\
\text { average BMl }\left(\mathrm{kg} / \mathrm{m}^{2}\right)\end{array}$ & 37.61 & 36.24 & 41.5 & 39.96 & 36.34 & 0.008 \\
\hline $\begin{array}{l}\text { End of follow-up } \\
\text { average \%EWL }\end{array}$ & 41.91 & 46.03 & 24.75 & 32.89 & 48.98 & 0.040 \\
\hline
\end{tabular}

Table 4. Number of patients who have comorbidities and their improvements

\begin{tabular}{|l|c|c|}
\hline Comorbidity & $\mathbf{n}(\mathbf{\%})$ & $\begin{array}{c}\text { Improvement in } \\
\text { disease } \mathbf{n}(\%)\end{array}$ \\
\hline Type 2 diabetes mellitus & $13(7.4)$ & $10(5.7)$ \\
\hline Essential hypertension & $16(9.1)$ & $11(6.3)$ \\
\hline Artralgia & $8(4.5)$ & $5(2.8)$ \\
\hline Sleep apnea & $6(3.4)$ & $4(2.2)$ \\
\hline Total & $43(24.7)$ & $30(17.2)$ \\
\hline & & \\
\hline
\end{tabular}

\section{DISCUSSION}

In the present study, we evaluated the long-term follow-up results of 174 patients who underwent LAGB operation. The study had the reliability that could be compared with the literature both in terms of the number of patients and in terms of follow-up rate. The average follow-up period of the patients was long enough to provide long-term results $(8,9)$.

An ideal bariatric surgery method should be a method that has the highest \%EWL and preferably reversible, in addition to the minimum morbidity and mortality rates. Therefore, gastric band application is a method that has been used for approximately 20 years in obesity (10).

In the literature, long-term outcomes regarding the method, a lot of complications, and reductions in percentages in the EWL were reported $(3,11)$. Many centers in Europe made the transition to other surgical procedures, primarily gastric bypass and sleeve gastrectomy (8). In our study, band removal has been accepted as a failure for LAGB surgery, and patients were referred to revision surgery. Considering all patients, mean \%EWL was $41.91 \%$. However, since this figure includes those patients who did not undergo another surgery after band removal and those patients who underwent revision surgery after band removal, it would be more accurate to exclude these groups to assess the LAGB operation.

There is no statistically significant difference between these four groups in terms of preoperative BMI and weight values. On the other hand, there is a statistically significant difference in terms of the end of follow-up weight, BMI, and \%EWL values. Especially, there is a significant difference between the group who was followed up by the band and the LSG group and the group who did not undergo another surgery. There is no statistically significant difference between the gastric bypass group and the group who was followed up by the band. This may suggest that the LAGB operation can be successful in weight loss as gastric bypass. However, considering the long-term results in our study, band removal and necessity of revision surgery have occurred in the majority of patients owing to various complications. O'Brien et al. published a systematic review in 2013 (12). The present study indicated similar long-term weight losses for LAGB and gastric bypass and also similar high rates of complications and necessity of revision surgery, such as our study (12).

When the mean \%EWL was considered, the most successful group is the gastric bypass group (49.98\%), followed by patients who were followed up with the band (46.03\%). It is not surprising that the most unsuccessful group is the group who was not performed another surgery after band removal. This situation demonstrates how necessary it is to apply revision surgery in patients in whom complication developed and also may show that gastric bypass may be the preferred revision procedure after LAGB. In the literature, there are many studies on revision surgery after failed LAGB. In these studies, patients who underwent revision surgery, with follow-up results of \%EWL values, are close to our study (13-15). Elhanas et al. published an ex- 
tensive review in 2013 about revision surgery and suggested gastric bypass as revision surgery for LAGB (15).

In 112 (64.36\%) patients who were followed up with the band, the mean \%EWL was $46.03 \%$, the preoperative average BMI was $48.5 \mathrm{~kg} / \mathrm{m}^{2}$, the end of follow-up average BMI was $36.2 \mathrm{~kg} / \mathrm{m}^{2}$. These rates are close to other studies in the literature $(8,9,11,16$ 18).

In our study, the most frequent complication among the major complications is band intolerance, which is also the most common cause of band removal. A total of 22 patients showed band intolerance, and 15 out of these patients did not respond to medical treatment; therefore, these patients' bands had to be removed. Whereas Suter et al. have reported esophagitis and pathological pH scores even shortly after the LAGB application, Gutschow et al. have shown esophagitis in 30\% of the patients and pathological pH scores in $43.8 \%$ of the patients in a study during an average 30-month follow-up period $(19,20)$. In addition to the presence of studies supporting that band intolerance may be due to very tight banding, in patients where the bands were loosened but no respond was received or reoccurrence of the condition was observed, it is obvious that factors, such as psychological or psychosocial factors of the patients, also need to be taken into consideration (17).

Band slippage was observed in 19 (10.91\%) patients. This rate varies between $3.6 \%$ and $6.9 \%$ in the literature $(8,16,17)$. Frequently performed adjustments in patients who cannot achieve optimal weight loss can be thought as a cause of high slippage rates.

The pouch enlargement rate (3.44\%) is lower than the literature $(8,9,16,17)$. In the literature, one of the most important causes of pouch enlargement was reported as overly inflated bands (21). We believe that the reason that our rate is lower than the literature is owing to the fact that patients were closely followed up, and their checks were performed in a timely manner.

The band erosion rate is at the same level with many studies or even at better levels $(9,11,17)$. Himpens et al. have associated the high erosion rate in their study to performing an endoscopic examination and use of the perigastric technique on every patient who gained weight even if there were no symptoms. On the other hand, Suter et al. believe that it is due to more than the 5-year follow-up period and performing routine endoscopy again (17). The reason that the incidence of band erosion in our study was lower than that in the literature may be due to the fact that endoscopy was performed only on those symptomatic patients, and that routine endoscopy was not performed.

The band was removed in $35.63 \%$ of our patients. The band removal rate in our study is consistent with the literature $(9,18,22)$. The cause of high band removal rate can be considered as band intolerance, which is the most common cause, and that patients did not change their dietary habits during that time. In our study, band removal was considered as a failure in LAGB operations, and patients were referred to revision surgery. Approximately half of the patients whose band was removed underwent a new operation, such as gastric bypass or sleeve gastrectomy. Patients were followed up to prevent weight gain in this way.

Our data showed that $69.7 \%(n=30)$ from all of the concomitant disease $(n=43)$ in patients with obesity healed after surgical treatment. The improvement rates of all concomitant disease based on type 2 diabetes mellitus, essential hypertension, and obstructive sleep apnea syndrome were $76.9 \%, 68.7 \%$, and $66.6 \%$, respectively. These results were consistent with the literature in patients who were morbidly obese who were treated surgically (23-25).

Twenty-one patients who were treated with gastric banding had concomitant diseases. We observed healing for comorbidities in 17 patients. The improvement rates of type 2 diabetes mellitus, hypertension, and arthralgia were statistically significant $(p<$ 0.05 ) in patients who were treated with gastric banding. These results were superior from the literature for patients who were morbidly obese who were treated with banding (23-25).

\section{CONCLUSION}

When improved patient compliance and careful and close patient follow-up are provided in the early stages of LAGB application, it may be possible to reach \%EWL results that would be the nearest to those achieved by gastric bypass or sleeve gastrectomy methods. However, high complication rates and necessity to perform other bariatric surgical procedures in the majority of the patients in the long-term follow-ups suggest that the LAGB operation is not the first choice in bariatric surgery.

In addition, it should be emphasized that it is important to apply a new bariatric surgical method to prevent weight gain after band removal.

Ethics Committee Approval: Ethics committee approval was received for this study from the Ethics Committee of Ankara Numune Training and Research Hospital (2013-545).

Informed Consent: Informed consent was not received due to the retrospective nature of the study.

Peer-review: Externally peer-reviewed.

Author Contributions: Consept - S.O., M.F.A.; Design - S.O., M.F.A.; Supervision - M.F.A., B.S.; Data Collection and/or Processing - S.O.; Analysis and Interpretation - S.O., M.F.A.; Literature Search - S.O.; Writing Manuscript - S.O., M.F.A.; Critical Reviews - B.S., M.F.A.

Conflict of Interest: The authors have no conflicts of interest to declare.

Financial Disclosure: The authors declared that this study has recevied no financial support 


\section{REFERENCES}

1. Banlı O, Altun H, Karakoyun R, Özdoğan H, Kahveci K, Çakmak B. Results of laparoscopic adjustable gastric band surgery for morbid obesity: First 100 cases. Turk J Surg 2009; 25: 11-4.

2. Sauerland S, Angrisani L, Belachew M, Chevallier J, Favretti F, Finer $N$, et al. Obesity surgery: evidence-based guidelines of the European Association for Endoscopic Surgery (EAES). Surg Endosc 2005; 19: 200-21. [CrossRef]

3. Suter M, Calmes J, Paroz A, Giusti V. A 10-year experience with laparoscopic gastric banding for morbid obesity: high long-term complication and failure rates. Obes Surg 2006; 16: 829-35. [CrossRef]

4. Ren CJ, Fielding GA. Laparoscopic adjustable gastric banding: surgical technique. J Laparoendosc Adv Surg Tech A 2003; 13: 257-63. [CrossRef]

5. Egan RJ, Monkhouse SJ, Meredith HE, Bates SE, Morgan JD, Norton SA. The reporting of gastric band slip and related complications; a review of the literature. Obes Surg 2011;21:1280-8. [CrossRef]

6. Suter M, Giusti V, Heraief E, Calmes JM. Band erosion after laparoscopic gastric banding: occurrence and results after conversion to Rouxen-Y gastric bypass. Obes Surg 2004; 14: 381-6. [CrossRef]

7. Deitel M, Greenstein RJ. Recommendations for reporting weight loss. Obes Surg 2003; 13: 159-60. [CrossRef]

8. Tolonen P, Victorzon M, Makela J. 11-year experience with laparoscopic adjustable gastric banding for morbid obesity - what happened to the first 123 patients? Obes Surg 2008; 18: 251-5. [CrossRef]

9. Himpens J, Cadiere GB, Bazi M, Vouche M, Cadiere B, Dapri G. Longterm outcomes of laparoscopic adjustable gastric banding. Arch Surg 2011; 146: 802-7. [CrossRef]

10. Egan RJ, Monkhouse SJ, Meredith HE, Bates SE, Morgan JD, Norton SA. The reporting of gastric band slip and related complications; a review of the literature. Obes Surg 2011;21: 1280-8. [CrossRef]

11. Martikainen T, Pirinen E, Alhava E, Poikolainen E, Paakkonen M, Uusitupa $M$, et al. Long-term results, late complications and quality of life in a series of adjustable gastric banding. Obes Surg 2004; 14:648-54. [CrossRef]

12. O'Brien PE, MacDonald L, Anderson M, Brennan L, Brown WA. Longterm outcomes after bariatric surgery: fifteen-year followup of adjustable gastric banding and a systematic review of the bariatric surgical literature. Ann Surg 2013; 257: 87-94. [CrossRef]

13. Tran TT, Pauli E, Lyn-Sue JR, Haluck R, Rogers AM. Revisional weight loss surgery after failed laparoscopic gastric banding: an institutional experience. Surg Endosc 2013;27: 4087-93. [CrossRef]
14. Liu K-H, Diana M, Vix M, Mutter D, Wu H-S, Marescaux J. Revisional surgery after failed adjustable gastric banding: institutional experience with 90 consecutive cases. Surg Endosc 2013; 27: 4044-8. [CrossRef]

15. Elnahas A, Graybiel K, Farrokhyar F, Gmora S, Anvari M, Hong D. Revisional surgery after failed laparoscopic adjustable gastric banding: a systematic review. Surg Endosc 2013; 27: 740-5. [CrossRef]

16. Weiner R, Blanco-Engert R, Weiner S, Matkowitz R, Schaefer L, Pomhoff I. Outcome after laparoscopic adjustable gastric banding - 8 years experience. Obes Surg 2003; 13: 427-34. [CrossRef]

17. Suter M, Calmes JM, Paroz A, Giusti V. A 10-year experience with laparoscopic gastric banding for morbid obesity: high long-term complication and failure rates. Obes Surg 2006; 16: 829-35. [CrossRef]

18. Belachew M, Belva PH, Desaive C. Long-term results of laparoscopic adjustable gastric banding for the treatment of morbid obesity. Obes Surg 2002; 12: 564-8. [CrossRef]

19. Suter M, Dorta G, Giusti V, Calmes JM. Gastric banding interferes with esophageal motility and gastroesophageal reflux. Arch Surg 2005; 140: 639-43. [CrossRef]

20. Gutschow CA, Collet P, Prenzel K, Holscher AH, Schneider PM. Longterm results and gastroesophageal reflux in a series of laparoscopic adjustable gastric banding. J Gastrointest Surg 2005; 9: 941-8. [CrossRef]

21. Blachar A, Blank A, Gavert N, Metzer U, Fluser G, Abu-Abeid S. Laparoscopic adjustable gastric banding surgery for morbid obesity: imaging of normal anatomic features and postoperative gastrointestinal complications. AJR Am J Roentgenol 2007; 188: 472-9. [CrossRef]

22. DeMaria EJ, Sugerman HJ, Meador JG, Doty JM, Kellum JM, Wolfe L, et al. High failure rate after laparoscopic adjustable silicone gastric banding for treatment of morbid obesity. Ann Surg 2001; 233: 809-18. [CrossRef]

23. Edwards MA, Grinbaum R, Schneider BE, Walsh A, Ellsmere J, Jones DB. Benchmarking hospital outcomes for laparoscopic adjustable gastric banding. Surg Endosc 2007; 21: 1950-6. [CrossRef]

24. Ji XR, Chen DL, Hu XG, WU JS, Ke CW, Yin K, et al. Laparoscopic adjustable gastric banding in the treatment of obesity: analysis of 172 cases. Zhonghua Wei Chang Wai Ke Za Zhi 2009; 12: 551-3.

25. Cunneen SA. Review of meta-analytic comparisons of bariatric surgery with a focus on laparoscopic adjustable gastric banding. Surg Obes Relat Dis 2008:4:547-555. [CrossRef] 
ORIJINAL ÇALIŞMA-ÖZET

Turk J Surg 2019; 35 (2): 79-85

\section{Laparoskopik ayarlanabilir gastrik bant uygulanan hastaların uzun dönem sonuçları}

Sabri Özden ${ }^{1}$, Barış Saylam¹, Fatih Mehmet Avşar ${ }^{1}$

${ }^{1}$ Ankara Numune Eğitim ve Araştırma Hastanesi, Cerrahi Kliniği, Ankara, Türkiye

\section{ÖZET}

Giriş ve Amaç: Morbid obezitede en etkili tedavi basamağı cerrahi tedavidir. Bu çalışmanın amacl; laparoskopik ayarlanabilir gastrik bant (LAGB) ameliyatı uygulanan hastalarda uzun dönem takip sonuçları ile başarı oranını irdelemektir.

Gereç ve Yöntem: Çalışmada Nisan 2006-Şubat 2012 arasında laparoskopik ayarlanabilir gastrik bant operasyonu yapılan 220 morbid obez hastada; 6 yıllık takip süresinde vücut kitle indeksindeki değişim, fazla kiloların kaybı (FKK) yüzdesi, ek hastalıklar ve düzelme oranı, oluşan komplikasyonlar, sıkığı ve yapılan tedaviler incelenmiştir. Rutin takiplerine gelmeyen 46 hasta çalışma dışı bırakılmıştır.

Bulgular: Çalışmamızda bant çıkarılma yüzdesi \%35,63'tür. Bant çıkarılmadan takip edilen hastalarda FKK \%46,03'tür. Major komplikasyonlar içinde en sık görülen komplikasyon; bant çıkarılmasının da en sık sebebi olan bant intoleransıdır. Bant çıkarılması LAGB operasyonu için başarısızlık olarak kabul edilmiş ve hastalar başka cerrahi yöntemlere yönlendirilmiştir.

Sonuç: İyi hasta uyumu, titiz ve yakın hasta takibi sağlandığında LAGB uygulaması ile erken dönemde gastrik baypas ya da sleevegastrektomi yöntemlerine yakın FKK yüzdesi sonuçlarına ulaşmak mümkün olabilir. Ancak uzun süreli takiplerde, yüksek komplikasyon oranları ve hastaların önemli bir kısmında diğer bariatrik cerrahi yöntemlere geçilmek zorunda kalınması, LAGB operasyonunun ancak seçilmiş hastalarda uygulanabileceğini düşündürmektedir.

Anahtar Kelimeler: Vücut kitle indeksi, laparoskopik ayarlanabilir gastrik bant, aşııı kiloların kaybı yüzdesi, laparoskopik sleeve gastrektomi, laparoskopik Roux-N-Y gastrik baypas

DOi: $10.5578 /$ turkjsurg.4038 